DOI 10.37882/2223-2982.2021.12-2.04

\title{
СОЦИОКУЛЬТУРНОЕ ВЗАИМОДЕЙСТВИЕ ПРИГРАНИЧНЫХ ТЕРРИТОРИЙ РОССИИ И БЕЛАРУСИ: НА ПРИМЕРЕ ДЕЯТЕЛЬНОСТИ УЧРЕЖДЕНИЙ КУЛЬТУРЫ
}

\section{SOCIOCULTURAL INTERACTION OF BORDER TERRITORIES OF RUSSIA AND BELARUS: ON THE EXAMPLE OF ACTIVITIES OF CULTURAL INSTITUTIONS}

\section{S. Asrieva}

Summary: In this article the topicality of theoretical and empirical studies of sociocultural interaction between the borderland territories of Russia and Belarus, which are the reference points of cooperation in the cultural sphere, is illustrated.

In the article the basic directions of cultural institutions of cross-border areas which have received dynamic development are considered, the socio-pedagogical conditions promoting the improvement of quality of life of the population of cross-border areas are revealed, the cultural forms of cooperation are analyzed.

Keywords: socio-cultural interaction, Russian-Belarusian borderland, cross-border cooperation, cross-border districts, cultural institutions.
Асриева Снежана Вячеславовна

К.п.н., дочент, ОГБОУ ВО «Смоленский государственный институт искусств» snezhana.smolensk@gmail.com

Аннотация: В данной статье подчёркивается актуальность теоретических и эмпирических исследований социокультурного взаимодействия приграничных территорий России и Беларуси, являющиеся опорными центрами сотрудничества в культурной сфере.

В статье рассмотрены основные направления учреждений культуры порубежных районов, получившие динамичное развитие, выявлены социально-педагогические условия, способствующие повышению качества жизни населения приграничья, анализируется культурные формы сотрудничества.

Ключевые слова: социокультурное взаимодействие, российско-белорусское приграничье, приграничное сотрудничество, порубежные районы, социокультурная интеграция.
B новой геополитической реальности процессы культурного взаимодействия осознаются как стратегический ресурс укрепления международных связей и углубления интеграции приграничных территорий сопредельных государств. Это в полной мере относится к российско-белорусскому приграничью. Об этом свидетельствует ряд документов, в частности, «Стратегия пространственного развития Российской Федерации на период до 2025 года», «Концепция приграничного сотрудничества в Российской Федерации» (утверждена распоряжением Правительства Российской Федерации от 7 октября 2020 г. № 2577-р). В документах акцентируется внимание на том, что «сотрудничество приграничных территорий приобретает первостепенное значение как формат общения, в рамках которого государства, регионы и муниципальные образования осуществляют культурное взаимодействие» [1].

Несмотря на то, что многие международные аналитики прогнозируют паузу в белорусско-русской интеграции, но, как и почти четверть века назад, усиливается стремление народов к объединительным тенденциям, в первую очередь - к культурному взаимодействию. Более того, культурные формы сотрудничества двух брат- ских народов не прерывались никогда, а как бы являются фактом «вопреки».

В силу такого положения, когда со стороны запада существуют реальные попытки оказать внешнее дестабилизирующее воздействие на отношения двух независимых государств, с каждым годом «вопреки» набирают обороты и реализуются социокультурные проекты, проводятся Дни культуры Республики Беларуси, визиты делегаций с культурными миссиями, межрегиональные форумы, выставки, фестивали, конкурсы.

Понять обсуждаемую проблему только на эмоциональном уровне невозможно, поэтому возникает необходимость теоретического и эмпирического исследования феномена «социокультурное взаимодействие» приграничных территорий.

Многие отечественные и зарубежные авторы рассматривают его в качестве важнейшей инструментальной единицы культурного процесса, которое складывается, по меньшей мере, между двумя народами, а также тех отношений, влияний, взаимных изменений, которые появляются в ходе этого процесса. Причём, значительную 
роль во взаимодействии культур имеет его структура, то есть те содержательные направления и конкретные формы взаимного обмена, через которые оно осуществляется [2].

Важно отметить, что базисным компонентом культурного взаимодействия выступает территория, которой свойственен специфический комплекс социальных и культурных отношений, видов деятельности, локальных практик. Особенно активными контактами отмечены взаимодействия соседних культур, а также народов, представители которых живут на одной и той же территории чересполосно.

Так исторически сложилось, что российско-белорусское приграничье оказалось на пересечении различных социокультурных, этнонациональных, государственных и цивилизованных образований. Ядро этого территориального образования - семь районов Смоленщины: три из них граничат с Витебской областью, четыре - с Могилевской областью.

Граница, проходящая между цивилизациями, нациями, государствами и территориями, выполняет функции разделения (обособления), так и соединения (общения), выступает как пространство перехода одного в другое, как контактная зона.

Своим географическим положением, ходом исторических событий, имеющее символическое значение, а также особенностями историко-социального развития народов, Смоленская область «обречена» на тесные связи с Белоруссией. Смоленщине на протяжении многих веков отводилась роль палимагистрали (культурные и иные коммуникации) между востоком и западом.

Приграничье уникально тем что, располагая культурно-историческим наследием, обладает огромным потенциалом формирования опорных центров сотрудничества в социокультурной сфере.

Именно в этом пространстве на протяжении многих веков существовал достаточно интенсивный культурный обмен, человеческий контакт, без которого невозможно сегодня плодотворное развитие ни одной из двух близкородственных культур. Здесь же активизируются и непосредственно налаживаются деловые и культурные контакты; обнаруживается ментальный разрыв или духовное родство; идёт сложный процесс отбора и закрепления парадигм дальнейшего развития, активизируются и непосредственно налаживаются деловые и культурные контакты.

В данном плане, перефразируя мысль М.М. Бахтина, высказанную в отношении культуры вообще, можно сказать и о российско-белорусском приграничье: «Не имея внутренней территории, она вся расположена на границах, границы проходят повсюду, через каждый момент её. Каждый культурный акт существенно живет на границах: в этом его серьезность и значительность; отвлеченный от границ, он теряет почву, становится пустым, заносчивым, вырождается и умирает» [4].

Признанием этого является тот факт, что начиная с 90 х годов XX, с образованием Союза России и Белоруссии и заключением соглашения о культурном партнёрстве между шестью областями Смоленской области и Республикой Беларусь, значительно активизировались культурные формы сотрудничества [5].

За двадцатилетний период культурного партнёрства учреждений культуры приграничных территорий динамичное развитие получили такие направления, как:

- содействие культурному обмену коллективами художественной самодеятельности;

- организация и реализация совместных социокультурных проектов, Дней культуры, праздничных мероприятий, проведение выставок, концертов, фестивалей;

- поддержка и проведение совместных исследований и мероприятий в области сохранения, возрождения и развития народных художественных промыслов и ремесел;

- усовершенствование деятельности методических центров в соответствии с современным развитием социокультурных процессов в регионе;

- обмен методиками культурно-досуговой работы, организация и проведение совместных семинаров, конференций, совещаний работников культуры по проблемам развития и сохранения историко-культурного наследия в областях.

Тем не менее, можно отметить и ряд проблем культурного партнёрства субъектов приграничных территорий. Во-первых, это отсутствие новые прорывных проектов, объединяющих социокультурных идей, которые можно принять за цель. Во-вторых, отсутствие новых способов взаимного общения и согласованных действий компетентных органов сторон, то есть заинтересованных органов исполнительной власти, организаций культуры, направленных в решении вопросов культурного сотрудничества субъектов, повышения качества жизни населения приграничья. В-третьих, сложным вопросом остаётся развития финансовых механизмов, которые служили бы привлечению инвестиций, как с российской, так и с белорусской стороны. К сожалению, на протяжении последних лет наметилась тенденция снижения расходов на культурные мероприятия. 
Однако, можно отметить, что важным стимулом развития приграничья является гранты. Именно на средства гранта Президента РФ на развитие гражданского общества, предоставленным при финансировании Фонда президентских грантов, поддерживается брендовый российско-белорусский проект «Две Руси - две сестры», который реализуется с 2006 года.

Исследуя проблему по данному вопросу, можно сделать вывод, что в новых условиях социокультурным системам двух стран, надо выстраивать новую модель культурного взаимодействия, основанную, как на традиционных ценностях предыдущего уклада, с другой стороны, отвечающую современным и перспективным целям.

Это возможно при соблюдении ряда социально-педагогических условий, на которые необходимо опираться для оптимального решения социокультурного взаимодействия приграничных территорий:

- создание новых брендовых социокультурных проектов, основанных на славянских культурных традициях, а также связанных с использованием историко-культурных ценностей;

- социокультурная активность широкого круга участников взаимодействующих сторон в систему интегрированного взаимодействия

- проектирование социокультурного пространства приграничья должно опираться на принципы сотрудничества и диалога;

- воспитание подрастающего поколения на традициях славянской культуры, формирование бережного отношения и любви к ней, развитие нравственных качеств личности, патриотизма;

- популяризация и бережное сохранение лучших образцов славянского народного творчества;

- формирование сети современных культурно-досуговых центров, способных максимально обеспечить население приграничья (вплоть до самых отдалённых населенных пунктов) качественными услугами;

- привлечение ведущих деятелей искусств, специалистов для оказания помощи в проведении социокультурных проектов, фестивалей.

- использование нестационарных форм культурного обслуживания, с использованием новых информационных технологий.

- совершенствование договорно-правовой базы: межгосударственные договоры, межправительственные и межведомственные соглашения и протоколы, договоренности между регионами, организациями и учреждениями культуры.

Наглядным примером, демонстрирующим торжество силы искусства и настоящего славянского братства, является Российско-белорусский международный фестиваль народного творчества «Две Руси - две сестры» в г.п. Хиславичи Смоленской области. Радушно гостей фестиваля принимает МБУК «Хиславичский районный центр культурно-досуговой работы и народного творчества».

Ярким доказательством единства, неразрывной связи, общих корней наших народов является Международный фестиваль самодеятельного художественного творчества «Порубежье». Начиная с 1999 года МБУК «Шумячская ЦСК» приняли талантливых самобытных исполнителей и творческих коллективов учреждений культуры Климовичского, Кричевского и Мстиславльского районов Могилевской области; Шумячского, Хиславичского, Ершичского, Починковского и Смоленского районов Смоленской области.

В целях укрепления и развития культурного сотрудничества регионов северо-западного порубежья, граничащих с Велижским районом Смоленской области, ежегодно проходит межрегиональный конкурс молодых исполнителей эстрадной песни «Велижская волна».

Таким образом, проанализировав особенности социокультурного взаимодействия приграничных территорий России и Республики Беларусь, можно сделать вывод, что учреждений культуры является опорными центрами сотрудничества, определяя его территориальный потенциал, способствующий взаимообогащению двух народов, при сохранении своей самобытности.

В настоящее время учреждения культуры в пределах своей компетенции определяют направления совместных культурных, творческих проектов, имеющих приоритетное значение для решения культурно-исторических задач и повышения социально-экономического роста региона. Всесторонняя поддержка творческих мероприятий в рамках федеральных и региональных программ, а так же грантов, фондов, договоров (контрактов) на оказание услуг в области культуры, способствует презентации разнообразной творческой продукции. Стратегии развития социокультурного развития приграничных территорий наиболее полно воплощаются в таких формах, как: фестивали, выставки, конференции, симпозиумы, семинары.

Подводя итоги, важно отметить, что в новых условиях культурного сотрудничества приграничных территорий процессы социокультурного взаимодействия имеют свою специфику, без учёта которых невозможно сохранение славянской культуры как определённой исторической и культурно - цивилизационной ценности. 


\section{ЛИТЕРАТУРА}

1. К Концепция приграничного сотрудничества в Российской Федерации»: утверждена распоряжением Правительства Российской Федерации от 7 октября 2020 г. № 2577-р // Министерств0 экономического развития Российской Федерации: официальный сайт. - URL: https://economy.gov.ru/material/ dokumenty/koncepciya_prigranichnogo_sotrudnichestva_v_rossiyskoy_federacii_html (дата обращения : 28.11.2021).

2. Ремизов В.А. Антиномичность культурно-цивилизованного диалога и современная Россия / В.А. Ремизов, М.А. Аракелян // Культура и образование. 2019. - № 1. - С. 5-15.

3. Борисёнок Ю.А. Белорусско-русское пограничье в условиях Российской империи: вторая половина XVIII - первая половина XIX в. / Ю.А. Борисёнок // Вопросы истории. - 2003. - № 5. - С. 116.

4. Пигалев, А. И. Пространство культуры / А.И. Пигалев // Культурология. XX век: энциклопедия. - Санкт-Петербург : Университетская книга, 1998. - 141 с.

5. Сотрудничество Шумячского, Хиславичского районов Смоленской области Российской Федерации и соседних районов Могилёвской области Республики Беларусь // Администрация муниципального образования

6. "Шумячский район" Смоленской области: официальный сайт. - URL : https://shumichi.admin-smolensk.ru/mezhdunarodnoe-sotrudnichestvo/informaciya-0-/

(c) Асриева Снежана Вячеславовна (snezhana.smolensk@gmail.com).

Журнал «Современная наука: актуальные проблемы теории и практики»

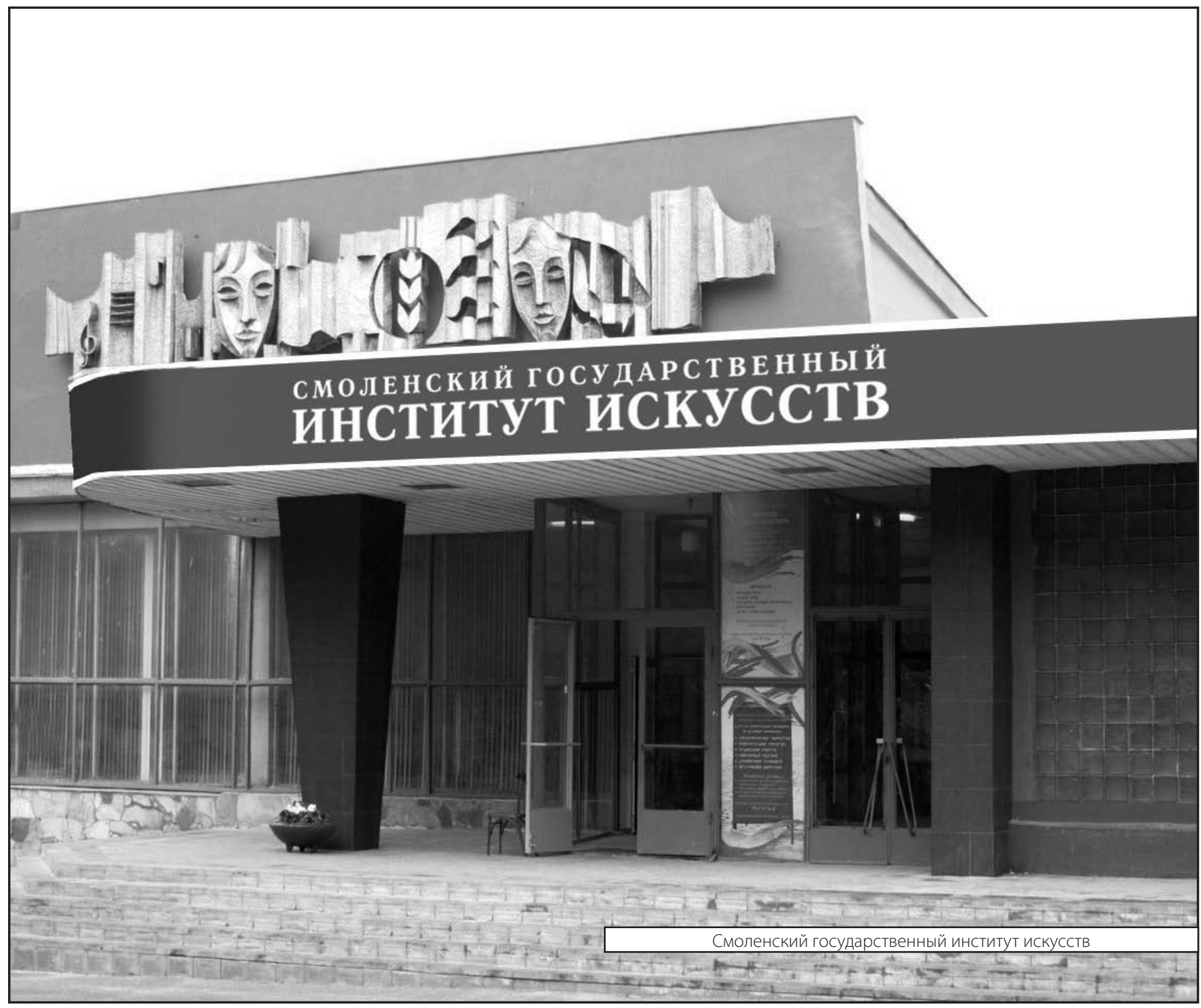

